In: Grumbach MM, Grave GD, Mayer FE (eds) The Control of the Onset of Puberty. John Wiley \& Sons Inc, New York, pp 115-116

22. Huseman CA, Kelch RP 1978 Gonadotropin responses and metabolism of synthetic gonadotropin-releasing hormone $(\mathrm{GnRH})$ during constant infusion of $\mathrm{GnRH}$ in men and boys with delayed adolescence. J Clin Endocrinol Metab 47:1325-1331

23. Valk TW, Corley KP, Kelch RP, Marshall JC 1980 Hypogonadotropic hypogonadism hormonal responses to low dose pulsatile administration of gonadotropin-releasing hormone. J Clin Endocrinol Metab 51:730-738

24. Caminos-Torres R, Ma L, Snyder PJ 1977 Testosterone-Induced Inhibition of the LH and FSH Responses to Gonadotropin-Releasing Hormone Occurs Slowly. J Clin Endocrinol Metab 44:1142-1153

25. Santen RJ 1975 Is aromatization of testosterone to estradiol required for inhibition of luteinizing hormone secretion in men? J Clin Invest 56:15551563
26. Winters SJ, Sherins RJ, Loriaux DL 1979 Studies on the role of sex steroids in the feedback control of gonadotropin concentrations in men. Ill. Androgen resistance in primary gonadal failure. $\mathrm{J}$ Clin Endocrinol Metab 48:553-558

27. Frager MS, Jakacki RI, Kelch RP, Marshall JC 1980 Testicular steroids regulate endogenous $\mathrm{GnRH}$ pulse amplitude. Clin Res 28:750A (abstr)

28. Ross JL, Loriaux DL, Cutler GB Jr 1983 Developmental changes in neuroendocrine regulation of gonadotropin secretion in gonadal dysgenesis. $\mathrm{J}$ Clin Endocrinol Metab 57:288-293

29. Kulin HE, Moore RG Jr, Santner SJ 1976 Circadian rhythms in gonadotropin excretion in prepubertal and pubertal children. J Clin Endocrinol Metab 42:770-773

30. Sauder SE, Case GD, Hopwood NJ, Kelch RP, Marshall JC 1984 Comparison of the effects of opiate antagonism on gonadotropin secretion in children and in women with hypothalamic amenorrhea. Pediatr Res 18:322-328

\title{
Red Cell Glycolytic Intermediates and Adenosine Triphosphate in Preterm Infants on the First Day of Life
}

\author{
SUSAN F. TRAVIS, SAVITRI P. KUMAR, LINDA M. SACKS, PATRICIA GILLMER, \\ MARIA DELIVORIA-PAPADOPOULOS \\ Department of Pediatrics and Cardeza Foundation for Hematologic Research, Jefferson Medical College, \\ Thomas Jefferson University and Departments of Pediatrics and Physiology, University of Pennsylvania School of \\ Medicine, Philadelphia, Pennsylvania 19102
}

\begin{abstract}
Red cell glycolytic intermediates and ATP were evaluated in 47 appropriate for gestational age preterm infants on the 1st day of life who were divided into three groups on the basis of gestational age: $28-30,31-$ 33, and 34-36 wk. The results were compared to those previously obtained in term infants. The concentrations of glucose-6-phosphate, total triose phosphates, and ATP were significantly higher than in term infants but appeared to be appropriately elevated for the young mean age of the red cell population. The concentration of red cell 2,3diphosphoglycerate (2,3-DPG) was significantly decreased when compared to term infants and was lowest at 28-30 wk gestation. The content of red cell 3 -phosphoglycerate was increased in term infants and was inappropriately elevated for the age of the red cell population at 28-30 wk gestation. This pattern of glycolytic intermediates was suggestive of a young red cell population metabolizing at an increased glycolytic rate with increased flow through the phosphoglycerate kinase step rather than the 2,3-DPG bypass in "normal" preterm infants. Two preterm infants of 28-30 wk gestation with low red cell intracellular $\mathrm{pH}$ were also evaluated and had markedly decreased concentrations of red cell 2,3-DPG and ATP and all phosphorylated intermediates distal to the phosphofructokinase reaction, indicative of a cross-over at the phosphofructokinase step secondary to acidosis. These studies demonstrate
\end{abstract}

Received June 15, 1984; accepted August 29, 1984

Send reprint requests to Susan F. Travis, M.D., Jefferson Medical College, Thomas Jefferson University, Department of Pediatrics, 1025 Walnut Street, Philadelphia, PA 19107.

Supported in part by NIH Grant HD-10213. that the "normal" preterm infant has a decreased concentration of red cell 2,3-DPG in the steady state and in the presence of acidosis additional red cell metabolic perturbations occur which lead to a further fall in red cell 2,3DPG and a decrease in the concentration of red cell ATP. (Pediatr Res 19: 117-121, 1985)

\section{Abbreviations}

PFK, phosphofructokinase

G-6-P, glucose-6-phosphate

2,3-DPG, 2,3-diphosphoglycerate

TTP, total triose phosphates

$P_{i}$, inorganic phosphorus

AGA, appropriate for gestational age

F-6-P, fructose-6-phosphate

3-PG, 3-phosphoglycerate

2-PG, 2-phosphoglycerate

PEP, phosphoenolpyruvate

RBC, red blood cells

PK, pyruvate kinase

DPGM, diphosphoglycerate mutase

PGK, phosphoglycerate kinase

The pattern of glycolytic enzymes and intermediates in newborn red cells differs from that observed in subjects with a red cell population of a similar mean age $(2,4,9,10,14,15,19,31$, 35). Metabolically, these cells appear to consume less glucose 
than would be predicted for red cells of such a young mean cell age (22). The relative deficiency of the regulatory enzyme, PFK, that is characteristic of neonatal red cells, has been proposed as a possible cause of this metabolic handicap (19). It has also been suggested that there is a "fetal" PFK isozyme $(11,12,34)$ in cord blood, and this isozyme is more inhibited by ATP (11) and may be less sensitive to $\mathrm{pH}$ activation (14) than the enzyme from adult red cells. Our laboratory has demonstrated that PFK has increased in vivo lability in cord blood (28), suggesting that the PFK deficiency in newborn red cells may be secondary to normal synthesis of an unstable enzyme.

It would be expected that the pattern of glycolytic intermediates might yield the most useful information regarding metabolic events at the in vivo level and the possible significance of the decreased enzyme activity and altered kinetic properties of PFK because the concentration of glycolytic intermediates at any particular time may reflect enzymatic flux, in vivo, according to the "cross-over theorem" of Chance et al. (3).

Red cell glycolytic intermediates have previously been evaluated in our laboratory in term infants (29). The concentration of G-6-P was elevated out of proportion to the age of the red cell population on the 1st day of life, continued to increase and peaked at 3-4 wk of age, at a time when the concentrations of red cell TTP and 2,3-DPG and the activity of PFK were similar to those observed at birth. Furthermore, the concentration of G6-P correlated significantly with the plasma $\mathrm{P}_{\mathrm{i}}$ concentration (20). These data suggested that the relative block in glycolysis at the PFK step and resulting pattern of glycolytic intermediates in term infants was not secondary to decreased PFK activity alone and that altered kinetic properties and/or modulation of PFK activity by extracellular factors such as $P_{i}$ may also play a significant role at the in vivo level.

It has previously been reported that the concentration of G-6-P is higher and 2,3-DPG is lower in preterm than in term infants suggestive of a more profound block in glycolysis at the PFK step in the preterm infant (19), but our laboratory has recently demonstrated higher PFK activity in premature than in term infants and no significant differences in PFK activity between preterm infants of 28-30 and 34-36 wk gestation (S. F. Travis, L. Sacks, S. Kumar, M. Delivoria-Papadopoulos, unpublished data). Thus, glycolytic intermediates were measured in 49 preterm infants who were divided into three groups on the basis of gestational age: $28-30,31-33$, and 34-36 wk in order to investigate the possible influence of the maturational age of the infant on the pattern of glycolytic intermediates. These results were compared to those previously obtained in term infants and subjects with a young red cell population (29) in order to evaluate further the possible relationship between the gestational age of the infant and red cell metabolism and the influence, if any, of differences in red cell enzyme activity on the pattern of glycolytic intermediates.

\section{MATERIALS AND METHODS}

Glycolytic intermediates were evaluated in 49 preterm infants on the 1st day of life. They were all AGA and were divided into three groups based on gestational age as determined by Dubowitz score (6): 28-30,31-33, and 34-36 wk, containing 12, 22, and 15 infants, respectively. Infants were studied as they became available which accounts for the different numbers of subjects in each group.

Extracts for glycolytic intermediates and ATP were prepared at the bedside: $2 \mathrm{ml}$ of heparinized blood were immediately pipetted into $4 \mathrm{~m}$ of chilled $2 \mathrm{~N}$ perchloric acid, reextracted and neutralized by methods previously described (29). Blood was obtained via venipuncture or through umbilical catheters when samples were being taken for other purposes. Informed consent was obtained. Cord blood and blood obtained without a steady flow were deemed unsuitable due to changes that can occur in the pattern of glycolytic intermediates when blood cannot be obtained and processed fairly rapidly.
Aliquots for determination of fetal $\mathrm{Hb}$ (27) and intracellular and extracellular $\mathrm{pH}(1)$ were removed when an adequate sample was obtained and rapidly processed. $\mathrm{A} \mathrm{Hb}$ and hematocrit were obtained on the remaining blood which was then centrifuged; the plasma was removed, recentrifuged, and frozen for later determination of $\mathrm{P}_{\mathrm{i}}(8)$. Intracellular $\mathrm{pH}$ was obtained in 26 infants; $P_{j}$ was determined on 42 samples; seven were obviously hemolyzed and were not evaluated. 2,3-DPG was determined spectrophotometrically by the Schroter and Heyden (26) modification of the technique of Krimsky (16). ATP was analyzed spectrophotometrically (17) by means of yeast HK (BMC Corp., Indianapolis, IN) and G-6-PD (BMC Corp.). Fructose diphosphate, glyceraldehyde-3-phosphate, and dihydroxyacetone phosphate were determined simultaneously as described by Keitt (13) and are referred to as TTP. G-6-P, F-6-P, 3-PG, 2-PG, and PEP were determined with modifications of the assay conditions described by Lowry et al. (18). G-6-P, F-6-P, TTP, 3-PG, 2-PG, and PEP were assayed fluorometrically with the use of an Eppendorf fluorometer (Brinkman Instruments) with a primary filter of $313 \pm 366 \mathrm{~nm}$ and a secondary filter of $400 \pm 3000 \mathrm{~nm}$. PK and fetal $\mathrm{Hb}(\% \mathrm{~F})$ data were previously evaluated (S.F. Travis, L. Sacks, S. Kumar, M. Delivoria-Papadopoulos, unpublished data).

In these studies, as in prior studies in term infants (29), PK activity was used as an index of red cell age in order to compare results obtained in infants with appropriately age-matched controls. PK was believed to be a valid parameter of red cell age since PK from cord red cells in term infants had been demonstrated in our laboratory $(28)$ to bear the same relationship between red cell age and density that had previously been demonstrated in red cells from adults $(24,25)$. In prior studies (29) there was wide variation in the mean age of the red cell population in subjects with similar degrees of reticulocytosis. They were thus divided into two groups based on PK activity: group I with a range of PK activity from 333.9 to 479.3 units/100 ml RBC representing a "moderately young" red cell population, and group II, that ranged from 518.4 to 820.9 units/100 ml RBC which represented a population of red cells with a very young mean cell age. By dividing subjects with reticulocytosis in this manner, it was believed that more accurate "age-matched" comparisons could be made between subjects with a young mean red cell age and term newborns.

Results obtained in preterm infants were compared to those previously obtained in term infants, normal subjects, and subjects with a young red cell population (29). Data were analyzed using the one-way analysis of variance (F statistic).

\section{RESULTS}

G-6-P, F-6-P, and TTP (Table 1). The concentrations of G-6-P and TTP were significantly higher in premature infants than in term infants at 28-30, 31-33, and 34-36 wk gestation. The increase in F-6-P was not statistically significant. There was no significant difference between the concentrations of G-6-P, F-6-P, or TTP at 28-30 and 34-36 wk gestation. The concentrations of G-6-P, F-6-P, and TTP were significantly higher than in subjects with a moderately young red cell population (group I) but not when compared to subjects with a very young red cell population (group II).

2,3-DPG and $A T P$ (Table 1). 2,3-DPG was significantly lower in preterm than in term infants at 28-30 and 31-33 wk but not at $34-36 \mathrm{wk}$ gestation. The mean concentration of $2,3-\mathrm{DPG}$ tended to decrease as the prematurity of the infants increased but those differences did not reach statistical significance.

In contrast, the mean red cell ATP concentration was higher in preterm infants than in term infants. This increase was significant at 28-30, and at 31-33 wk, but not at 34-36 wk gestation. Mean ATP concentration was higher at 28-30 than at 34-36 wk gestation but the difference was not significant. The ATP concentration at 28-30 wk was significantly higher than group I, but not group II. 


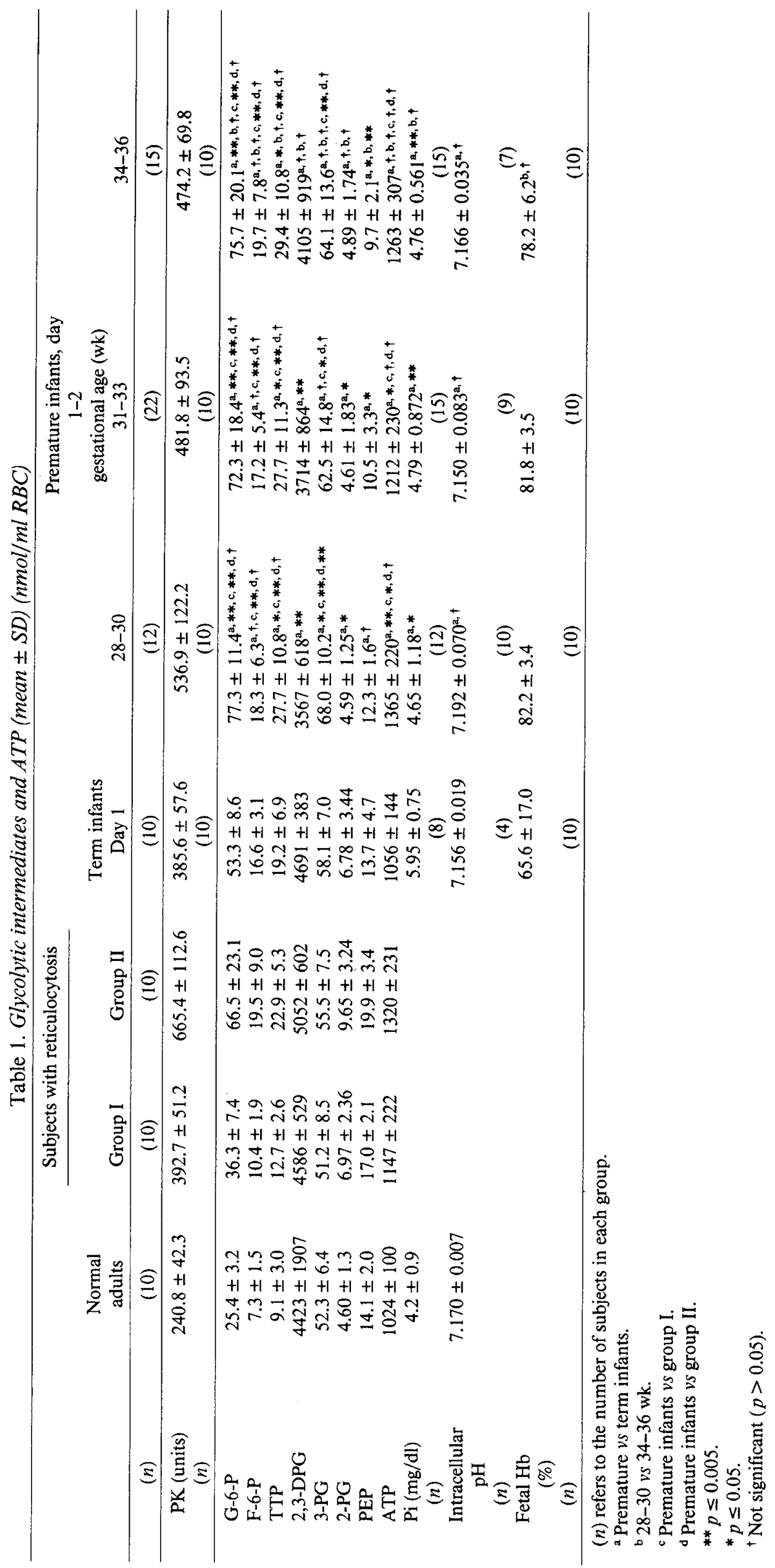


Table 2. Red cell glycolytic intermediates* in two premature infants with a low red cell intracellular $\mathrm{pH}$

\begin{tabular}{|c|c|c|c|}
\hline Gestational age & $\begin{array}{c}\text { A } \\
28-30 \text { wk }\end{array}$ & $\begin{array}{c}\text { B } \\
28-30 \text { wk }\end{array}$ & $\begin{array}{l}\text { Controls } \dagger 28- \\
30 \text { wk (mean } \\
\pm \mathrm{SD})\end{array}$ \\
\hline G-6-P & 65.8 & 60.2 & $77.3 \pm 11.4$ \\
\hline F-6-P & 19.5 & 10.8 & $18.3 \pm 6.3$ \\
\hline TTP & 5.3 & 6.0 & $27.7 \pm 10.8$ \\
\hline 2,3-DPG & 2281 & 1882 & $3567 \pm 618$ \\
\hline 3-PG & 46.4 & 20.6 & $68.0 \pm 10.2$ \\
\hline $2-\mathrm{PG}$ & 2.2 & 4.2 & $4.59 \pm 1.25$ \\
\hline PEP & 8.0 & 7.2 & $12.3 \pm 1.6$ \\
\hline ATP & 650 & 750 & $1365 \pm 220$ \\
\hline Intracellular pH & 6.866 & 7.010 & $7.192 \pm 0.070$ \\
\hline $\begin{array}{l}\text { PK activity } \\
\text { (units/100 ml } \\
\text { RBC) }\end{array}$ & 479.4 & 556.5 & $536.9 \pm 122.2$ \\
\hline
\end{tabular}

3-PG, 2-PG, and PEP. The mean concentration of red cell 3$P G$ was higher in preterm than in term infants, but this increase was only statistically significant at $28-30 \mathrm{wk}$ gestation, not at $31-33$ or $34-36$ wk gestation. Red cell $3-P G$ was significantly higher than group I at 28-30, 31-33, and 34-36 wk gestation. The 3-PG concentration was also significantly higher than group II at $28-30 \mathrm{wk}$, but not at $31-33$ or 34-36 wk gestation. There was no statistical difference in the 3-PG concentration between 28-30 and 34-36 wk or $28-30$ and $31-33$ wk gestation.

The concentration of red cell 2-PG was significantly higher in term than in preterm infants of $28-30$ and $31-33$ wk but not at 34-36 wk gestation. There was no significant difference in the 2-PG concentration between $28-30$ and $31-33$ wk or $28-30$ and 34-36 wk gestation.

The PEP concentration was significantly lower in preterm than in term infants at 34-36 and 31-33 wk but not at 28-30 wk gestation. There was a statistically significant difference in the PEP concentration between $28-30$ and 34-36 wk, but not between 28-30 and 31-33 wk and 31-33 and 34-36 wk gestation.

$P_{\mathrm{i}}$ and intracellular $p H$ (Table 1). Mean $\mathrm{P}_{\mathrm{i}}$ was lower in preterm than in term infants and this difference was significant at 28-30, $31-33$, and at $34-36 \mathrm{wk}$, but there was not a significant difference between $28-30$ and $34-36$ wk gestation.

Intracellular $\mathrm{pH}$ was not significantly different in preterm and term infants.

Red cell glycolytic intermediates in two preterm infants with a low red cell intracellular pH (Table 2). Samples from two infants of 28-30 wk gestation with low red cell intracellular $\mathrm{pH}$ of 6.866 and 7.010 were inadvertently obtained. The concentrations of red cell 2,3-DPG and ATP and all phosphorylated intermediates distal to the PFK reaction (TTP, 3-PG, 2-PG, and PEP) were markedly decreased. The levels of red cell G-6-P and F-6-P were nearly normal for the age of the red cell population (as estimated using red cell PK activity as an index of mean red cell age).

\section{DISCUSSION}

Analysis of glycolytic intermediates in preterm infants of 28 $30,31-33$, and $34-36 \mathrm{wk}$ gestation has revealed a significantly increased concentration of G-6-P and TTP when compared to term infants and subjects with a moderately young red cell population (group I), but the increased mean concentrations of G-6-P and TTP were not statistically significant when compared to subjects with a very young red cell population (group II). PK activity is also significantly increased in preterm infants (32) and it is likely that the increased concentrations of G-6-P and TTP in preterm infants are consistent with a red cell population of a younger mean red cell age.

The mean concentrations of red cell 3-PG and ATP were also higher in preterm than in term infants, but this increase was significant only in the most premature infants $(28-30 \mathrm{wk}$ gestation). The ATP concentration in preterm infants of $28-30 \mathrm{wk}$ gestation was significantly higher than in group I, but not group II, whereas the 3-PG concentration was significantly higher in all three groups of preterm infants than in group I and was also significantly greater than group II at $28-30$ wk gestation. These data suggest that the concentration of red cell 3-PG was elevated out of proportion to the age of the red cell population. The concentrations of red cell ATP and 3-PG were highest in the most premature infants although the differences between 28-30 and 34-36 wk gestation were not statistically significant.

In contrast, the mean concentration of red cell 2,3-DPG was lower in preterm than in term infants; this decrease was significant at 28-30 and 31-33 wk gestation but not at 34-36 wk. Mean 2,3-DPG tended to be lowest in the most immature infants, but differences in the red cell 2,3-DPG concentration at 28-30 and 34-36 wk gestation did not reach statistical significance.

Although there were no significant differences in the concentrations of red cell 2,3-DPG, ATP, and 3-PG between 28-30 and 34-36 wk gestation, the most significant changes occurred at 2830 wk gestation (i.e. increased concentrations of 3-PG and ATP and decreased 2,3-DPG).

The finding of an increased concentration of red cell G-6-P, F-6-P, TTP, 3-PG, and ATP in association with a decreased concentration of 2,3-DPG and a young mean red cell age appears to be most compatible with red cells metabolizing at an increased glycolytic rate with increased flow through the PGK reaction, which is an ATP generating step, rather than the 2,3-DPG bypass. A relative block in glycolysis at the PFK reaction could also contribute to the decreased concentration of 2,3-DPG and increased concentration of G-6-P as previously proposed (19), but the concentration of TTP in premature infants was significantly increased, whereas a decrease in the TTP concentration would be anticipated if there were a cross-over at the PFK reaction. Thus, the relative deficiency of PFK known to exist in newborns would be an unlikely contributing factor to the decreased concentration of red cell 2,3-DPG observed in preterm infants. The markedly increased activity of PGK may have contributed to the elevated 3-PG concentration, but the 3-PG concentration was higher in the red cells of preterm infants than in term infants, despite similar PGK activity, which suggests that increased PGK activity alone was not responsible for the increased concentration of 3-PG found in the red cells of preterm infants.

Alternatively, it could be postulated that the increased concentration of 3-PG was secondary to a metabolic block at or distal to the mutase step, especially since the concentrations of 2-PG and PEP were decreased. A metabolic block distal to the 2,3DPG bypass, however, should result in an increase in the 2,3DPG concentration, not the decrease that was observed. In addition, the activities of red cell enolase and pyruvate kinase have been measured in our laboratory (S.F. Travis, L. Sacks, S. Kumar, M. Delivoria-Papadopoulos, unpublished data) and both enzymes are significantly increased in preterm infants.

It has been demonstrated that red cells from neonates have greater 2,3-DPG instability $(21,33,36)$ than red cells from adults in vitro when incubated under identical conditions. Thus, 2,3DPG instability could also conceivably have contributed to the decreased 2,3-DPG concentration and increase in the concentrations of 3-PG and ATP. This 2,3-DPG instability was believed to be secondary to increased 2,3-DPG breakdown by Trueworthy and Lowman (33) and Oski and Komazawa (21), but Zipursky et al. (36) believed that it was due to decreased 2,3-DPG synthesis. Decreased 2,3-DPG synthesis in neonatal red cells has been previously demonstrated in vitro (23). Maximal stimulation of red cell glucose consumption at $\mathrm{pH} 8.2$ resulted in a greater increase in red cell 2,3-DPG in adults and subjects with a young red cell population than in neonates, suggestive of decreased flow through the 2,3-DPG bypass. It has also been reported (20) that red cells from adults, but not neonates, demonstrated a rapid increase in 2,3-DPG when incubated under nitrogen, although red cell glycolysis was stimulated in both adults and newborns. 
It was believed that the affinity of 2,3-DPG for deoxy fetal $\mathrm{Hb}$ was insufficient to facilitate the generation of additional 2,3DPG, whereas in the adult, 2,3-DPG preferentially binds deoxy $\mathrm{Hb} \mathrm{A}$, thus relieving the end product inhibition of DPGM by 2,3-DPG and allowing further synthesis of 2,3-DPG. It was suggested that under circumstances of hypoxia, neonatal red cells may have preferential flow through the PGK reaction whereas metabolism in red cells from adults flows preferentially through the DPGM reaction (7).

The pattern of red cell glycolytic intermediates obtained in the present study suggests that similar mechanisms may be operative at the in vivo level as well, and that the higher fetal $\mathrm{Hb}$ concentration present in preterm infants, which tends to increase with decreasing gestational age, may have led to preferential flow through the PGK reaction rather than the 2,3-DPG bypass, resulting in the observed decrease in the concentration of red cell 2.3-DPG and increase in red cell 3-PG and ATP.

$P_{i}$ and intracellular $\mathrm{pH}$ were also evaluated in preterm infants on the 1st day of life since acidosis can result in a decrease in 2,3-DPG (5) and increased $P_{i}$ was correlated with an elevated red cell G-6-P concentration in term infants $(30)$. $P_{i}$ was slightly higher than in adults but was lower than in term infants; intracellular $\mathrm{pH}$ was normal, suggesting that $\mathrm{P}_{\mathrm{i}}$ and intracellular $\mathrm{pH}$ do not contribute to the differences observed in the pattern of glycolytic intermediates in "normal" preterm infants on the 1st day of life. However, samples from two preterm infants of $28-$ $30 \mathrm{wk}$ gestation with a very low intracellular $\mathrm{pH}$ of 6.87 and 7.01 were inadvertently obtained and evaluated. They were found to have markedly decreased levels of 2,3-DPG, ATP and all phosphorylated intermediates distal to the PFK reaction and near normal levels of G-6-P and F-6-P. This pattern of glycolytic intermediates revealed a cross-over at the PFK reaction and represents an in vivo demonstration of decreased glycolysis at low pH secondary to inhibition of PFK activity.

Thus, our studies of red cell glycolytic intermediates in preterm infants were believed to be most compatible with a young red cell population and an increased glycolytic rate (leading to an increased concentration of G-6-P, F-6-P, and TTP) with preferential flow through the $\mathrm{PGK}$ reaction resulting in a significantly decreased concentration of 2,3-DPG and an increase in 3-PG and ATP in normal preterm infants. It is possible that decreased 2,3-DPG stability may also have contributed to the decrease in 2,3-DPG and increase in the 3-PG and ATP concentrations. These changes were most marked at $28-30$ wk gestation. Red cell PFK did not appear to contribute significantly to the decreased concentration of red cell 2,3-DPG in "normal" preterm infants. However, two acidotic infants had markedly decreased concentrations of 2,3-DPG and ATP and all phosphorylated intermediates distal to the PFK reaction secondary to inhibition of PFK activity at low $\mathrm{pH}$.

It is apparent from these studies of red cell glycolytic intermediates that the "normal" preterm infant has a decreased concentration of 2,3-DPG secondary to either decreased synthesis of 2,3-DPG and/or increased 2,3-DPG instability and the level of 2,3-DPG can decrease further in the presence of hypoxemia and/or acidosis. This is particularly pertinent in the smallest preterm infants who not only have a high fetal $\mathrm{Hb}$, lower zoncentration of red cell 2,3-DPG, and more left shifted oxygenhemoglobin dissociation curve than the term infant under "normal" circumstances but are also at greatest risk for developing respiratory distress syndrome, infections, and other problems which are associated with hypoxia and acidosis which may then lead to further red cell metabolic perturbations.

\section{REFERENCES}

1. Battaglia FC, Behrman RE, Hellegers AE, Battaglia JD 1965 Intracellular hydrogen ion concentration changes during acute respiratory acidosis and alkalosis. J Pediatr 66:737

2. Caruso P, Conti F, Londrillo A 1963 Diagramma delle attivita enzymatiche endoeritrocitarie nel neonato, nel lattante, nel bambino. Minerva Pediatr 15:1136
3. Chance B, Holmes W, Higgins J 1958 Localization of interaction sites in multicomponent transfer systems: Theorems derived from analogues. Nature $182: 1190$

4. Cotte J, Nivelon L, Cuivre M, Kissin C, Gessen-Campos J, Bethenod M, Mathieu M 1967 Les enzymes de la glycolyse intra-erythrocytaire chez le premature. Ann Pediatr 43:3158

5. Delivoria-Papadopoulos M, Roncevic NP, Oski FA 1971 Postnatal changes in oxygen transport of term, premature, and sick infants: the role of red cell 2,3-diphosphoglycerate and adult hemoglobin. Pediatr Res 5:235

6. Dubowitz L, Dubowitz V, Goldberg C 1970 Clinical assessment of gestational age in newborn infants. $J$ Pediatr $77: 1$

7. Duhm J, Gerlach E 1971 On the mechanism of the hypoxia-induced increase of 2,3-diphosphoglycerate in erythrocytes. Pflugers Arch 326:254

8. Fiske CH, Subbarow Y 1925 The colorimetric determination of phosphorus. J Biol Chem 66:375

9. Gahr M, Meves H, Schroter W 1979 Fetal properties in red blood cells of newborn infants. Pediatr Res 13:1231

10. Gross RT. Schroeder EAR, Brounstein SA 1963 Energy metabolism in the erythrocytes of premature infants compared to full term newborn infants and adults. Blood 21:755

11. Kahn A, Boyer C, Cottreau D, Marie J, Boivin P 1977 Immunologic study of the age-related loss of activity of six enzymes in the red cells from newborn infants and adults-Evidence for a fetal type of erythrocyte phosphofructokinase. Pediatr Res 11:271

12. Kahn A, Cottreau D, Boyer C, Marie J, Galand C, Boivin P 1976 Causal mechanisms of multiple acquired red cell enzyme defects in a patient with acquired dyserythropoiesis. Blood 48:653

13. Keitt AS 1969 Hemolytic anemia with impaired hexokinase activity. J Clin Invest 48:1997

14. Komazawa M, Oski FA 1975 Biochemical characteristics of "young" and "old" erythrocytes of the newborn infant. J Pediatr 87:102

15. Konrad PN, Valentine WN, Paglia DE 1972 Enzymatic activities and glutathione content of erythrocytes in the newborn: comparison with red cells of older normal subjects and those with comparable reticulocytosis. Acta Haematol 48:193

16. Krimsky I 1963 D-2,3-diphosphoglycerate. In: Bergmeyer HU (ed) Methods of Enzymatic Analysis, 1st ed. Academic Press, New York, p 238-240

17. Lamprecht W, Trautschold I 1963 Adenosine-5'-triphosphate. Determination with hexokinase and glucose-6-phosphate dehydrogenase. In: Bergmeyer HU (ed) Methods of Enzymatic Analysis, 1st ed. Academic Press, New York, p 543-551.

18. Lowry OH, Passonneau JV, Hasselberger FX, Schultz DW 1964 Effect of ischemia on known substrates and cofactors of the glycolytic pathway in brain. J Biol Chem 239:18

19. Oski FA 1969 Red cell metabolism in the newborn infant. V. Glycolytic intermediates and glycolytic enzymes. Pediatrics 44:84

20. Oski FA, Gottlieb AJ, Miller WW, Delivoria-Papadopoulos M 1970 The effects of deoxygenation of adult and fetal hemoglobin on the synthesis of red cell 2,3-diphosphoglycerate levels and its in vivo consequences. J Clin Invest 49:400

21. Oski FA, Komazawa M 1975 Metabolism of the erythrocytes of the newborn infant. Semin Hematol 12:209

22. Oski FA, Smith C 1968 Red cell metabolism in the premature infant. III. Apparent inappropriate glucose consumption for cell age. Pediatrics 41:473

23. Oski FA, Travis SF 1972 Effect of $\mathrm{pH}$ on glycolysis in the erythrocytes of the newborn infant. Pediatr Res 6:366 (abstr)

24. Piomelli S, Corash LM, Davenport DD, Miraglia J, Amorosi EL 1968 In vivo lability of glucose-6-phosphate dehydrogenase in $\mathrm{Gd}^{\mathrm{A}-}$ and $\mathrm{Gd}^{\text {Mediterrancan }}$ deficiency. J Clin Invest 47:940

25. Piomelli S, Lurinsky G, Wasserman LR 1967 The mechanism of red cell aging. I. Relationship between cell age and specific gravity evaluated by ultracentrifugation in a discontinuous density gradient. J Lab Clin Med 69:659

26. Schroter W, Heyden H 1965 Kinetik des 2,3-Diphosphoglyceratumsatzes in Menschlichen Erythrocyten. Biochem Z 341:387

27. Singer K, Chernoff AI, Singer L 1951 Studies on abnormal hemoglobins. I. Their demonstration in sickle cell anemia and other hematologic disorders by means of alkalai denaturation. Blood 6:413

28. Travis SF, Garvin JH Jr 1977 In vivo lability of red cell phosphofructokinase (PFK) in term infants: The possible molecular basis of the relative PFK deficiency in neonatal red cells. Pediatr Res 11:1159

29. Travis SF, Kumar SP, Delivoria-Papadopoulos M 1981 Red cell metabolic alterations in postnatal life in term infants: Glycolytic intermediates and adenosine triphosphate. Pediatr Res 15:34

30. Travis SF, Kumar SP, Delivoria-Papadopoulos M 1981 Red cell metabolic alterations in postnatal life in term infants: possible control mechanisms. Pediatr Res 15:133

31. Travis SF, Kumar SP, Paez PC, Delivoria-Papadopoulos M 1980 Red cell metabolic alterations in postnatal life in term infants: glycolytic enzymes and glucose-6-phosphate dehydrogenase. Pediatr Res 14:1349

32. Deleted in proof.

33. Trueworthy RC, Lowman JT 1971 Intracellular control of the 2,3-diphosphoglycerate (DPG) concentration in fetal red cells. Prog Soc Pediatr Res p 86 (abstr)

34. Vora S, Piomelli S 1977 Fetal isozyme of phosphofructokinase in newborn erythrocytes. Pediatr Res 11:483 (abstr)

35. Wang W, Mentzer WC 1976 Differentiation of transient erythroblastopenia of childhood from congenital hypoplastic anemia. J Pediatr 88:784

36. Zipursky A, LaRue T, Israels LG 1960 The in vitro metabolism of erythrocytes from newborn infants. Can J Biochem Physiol 38:727 